Villanova School of Business Economics Working Paper \#24

\title{
Excess Reserves and Economic Activity
}

\author{
Scott J. Dressler* \\ Erasmus K. Kersting \\ Villanova University \\ Villanova University
}

July 2013

\begin{abstract}
This paper examines a DSGE environment with endogenous excess reserve holdings in the banking sector. Excess reserves act as an extensive margin of bank lending which is inactive in traditional limited participation models where banks hold minimal reserves by assumption. The results of our model suggest that this extensive margin of bank lending can dampen and even overcome the standard liquidity effect of monetary contractions, amplify the output response to productivity shocks, and bring about large, short-run responses to changes in the interest rate paid on reserves.
\end{abstract}

Keywords: Financial Intermediation; Excess Reserves; Liquidity Effect; Output Amplification

JEL: C68; E44

*Corresponding author. Address: Villanova University; 800 Lancaster Avenue; Villanova, PA 19085-1699. Phone: (610) 519-5934. Fax: (610) 519-6054. Email: scott.dressler@villanova.edu. 


\section{Introduction}

We are currently experiencing an episode in which the banking system holds unprecedented amounts of excess reserves. Since September 2008, the ratio of total to required reserves of all depository institutions has been over 15.9 on average, while the same ratio one decade earlier was only 1.04 on average. Is this cause for alarm? Keister and McAndrews (2009) make a convincing argument that the large increase in excess reserves was simply a by-product of the Federal Reserve's lending facilities and asset purchase programs, and neither a sign of policy ineffectiveness nor impending doom. Nonetheless, there is surprisingly little work in the existent literature that analyzes how even moderate amounts of excess reserves in the banking system influence the predictions of an otherwise canonical economic model. This paper attempts to fill this gap in the literature by analyzing an economic environment where banks endogenously distribute their loanable funds between traditional loans and excess reserves. Taking the level of excess reserves as given, the paper then asks how the environment responds to standard monetary and productivity shocks, and how these responses compare to a baseline environment without excess reserves. Understanding how an economy functions with excess reserve balances is highly relevant given the fact that we will certainly be observing high levels of excess reserves when the Federal Reserve begins undoing the policies enacted during the recent financial crisis.

The environment analyzed in this paper has some similarities to a standard limited participation model: firms are required to finance a portion of their wage bill prior to production, monetary transfers are given to the banking sector before lending takes place, and the timing of decisions delivers a market segmentation which can potentially give rise to the standard liquidity effect of monetary contractions. We add two features to this basic framework. First, households are able to purchase portions of consumption with previously chosen currency and deposit holdings similar to Freeman and Kydland (2000). Having deposits purchase a portion of consumption departs from standard models which essentially treat deposits as nominal bonds, and minimizes the impact of households' deposit decisions on aggregate 
prices. The second and most novel feature we add is an idiosyncratic loan facilitation cost to banks. In particular, all banks are ex-ante identical and therefore receive identical amounts of deposits. After the monetary transfer, all banks draw an idiosyncratic cost from a known distribution which they must incur in order to make loans. This cost can be interpreted as a real fee for banks to either assess, monitor, or facilitate a loan. Taking all interest rates as given, each bank then decides if it is optimal to incur the cost and lend their assets or hold them as excess reserves. This feature delivers a portion of the banking sector which chooses to hold only excess reserves in steady state while avoiding some complicated computational issues associated with occasionally binding reserve constraints on the individual bank's problem. ${ }^{1}$

Our analysis suggests that excess reserves can result in drastic departures in the responses to monetary and productivity shocks from a baseline model that has zero excess reserves by assumption. With respect to a monetary contraction, we find that excess reserve holdings can either substantially dampen the increase in the nominal interest rate or even lead to a decline. In other words, the liquidity effect of a monetary contraction is either very small or nonexistent in an environment with excess reserves. Furthermore, when a monetary contraction leads to a reduction in nominal interest rates, it also delivers an increase in real output. With respect to a productivity shock, we find that the level of excess reserves in the banking sector is directly related to the amount of shock amplification. For example, we find that an economy with 30 percent excess reserves in the banking sector has more than a 35 percent larger output response to a productivity shock than an economy with zero excess reserves. The analysis concludes with an exercise determining how the environment responds to an increase in the interest paid on reserve holdings much like the policy maintained by the Federal Reserve since October 6, 2008. We find that the short-run impact of an increase in the interest rate paid on reserves can be substantial, and the magnitude of the impact is

\footnotetext{
${ }^{1}$ This mechanism is similar to Hopenhayn (1992), Carlstrom and Fuerst (1997), and other work modeling economic agents who receive idiosyncratic productivity draws and consequently choose to be active or passive due to fixed costs.
} 
directly related to the amount of excess reserves in the banking sector prior to the interest rate change.

The intuition behind our results is clearest in direct comparison to a model with zero excess reserves. For example, a monetary contraction in a standard limited participation model results in all banks reducing their current supply of loans. In other words, a monetary contraction reduces the intensive margin of lending. Explicitly considering excess reserves in a model effectively activates an extensive margin of loan supply which has the potential to offset and even overcome the intensive margin. In our model, a monetary contraction reduces the intensive margin of lending as in the standard case, but the impact is only felt on the loan supply of active banks that chose to make loans prior to the shock. In contrast, passive banks that chose to hold excess reserves can now decide to enter the loan market in response to the shock. The decrease in lending due to the intensive margin can therefore be completely offset by the increase in lending due to the extensive margin. The same intuition applies to the amplification of productivity shocks. The extensive margin of lending can increase in response to a rise in productivity and reduce the financing costs for firms, which in turn adds to the positive effect on output.

Finally, we analyze the effects of the central bank policy to pay interest on bank reserves. For obvious reasons the version of the model with zero excess reserves cannot serve as a benchmark in this case. Instead, we compare the effects on economies with various levels of excess reserves in the system. We find that high (low) excess reserve levels in the banking sector makes lending activity more (less) sensitive to the repercussions caused by the change in interest payments on reserves. If one subscribes to the view that large excess reserve holdings are a sign of inefficiency in the banking sector, then our result follows Ireland (2012), who states that the effects of paying interest on reserves can be large in economies with less efficient banking sectors.

To our knowledge, this is the first paper which considers a DSGE model that treats excess reserves as completely idle assets and compares its predictions to a model with zero excess 
reserves. ${ }^{2}$ Nonetheless, this analysis is related to several strands of the literature. First, there is the literature on the recent financial crisis such as Gertler and Kiyotaki (2010), Gertler et al. (2012), and Sunnikov and Brunnermeier (2012). These papers focus on real financial frictions and risk along the lines of Bernanke et al. (1999), and do not explicitly consider banking and reserve holdings. While our paper is motivated by the recent financial crisis, it should be stressed that the model analyzed here takes the level of excess reserves as given and focuses on the otherwise normal operating procedure of the banking system. ${ }^{3}$ Second, there is the literature on reserve management at the individual bank level such as Bartolini et al. (2001) and Clouse and Dow (2002). These papers examine the reserve holdings of commercial banks at the daily frequency and uncover a high-frequency liquidity effect in the data. Our finding of an unstable liquidity effect at the quarterly frequency supports Thornton's (2010) critique of this literature in so far as a daily liquidity effect does not necessarily identify a policy relevant liquidity effect. Finally, there is a large literature considering the policy of paying interest on reserve holdings. ${ }^{4}$ While our exercise touches on this issue only briefly, the results support Ireland's (2012) conclusion that paying interest on reserves can deliver sizeable, short-run effects in an economy with an inefficient banking sector.

The paper is organized as follows. Section 2 presents the model. Section 3 analyzes the model dynamics. Section 4 concludes.

\footnotetext{
${ }^{2}$ Papers like Chari et al. (1995) do consider excess reserves in the banking sector, but they are held in equilibrium solely because they are assumed to be a necessary input to a loan creation technology.

${ }^{3}$ This paper could therefore be considered a first step in the analysis of excess reserves since it abstracts from why the banking sector is holding them. This approach sidesteps the difficult issue of assessing how much of the current level of excess reserves is held due to the perception of risk or due to the current Federal Reserve policy of paying interest on reserves.

${ }^{4}$ This issue was first considered by Sargent and Wallace (1985) and Smith (1991). More current contributions to this literature are Goodfriend (2002), Ennis and Weinberg (2007), Keister et al. (2008), Berentsen and Monnet (2008), and Ireland (2012).
} 


\section{The Environment}

Time is discrete and the horizon is infinite. All nominal prices are perfectly flexible. The economy is populated by a large number of identical and infinitely-lived households, a large number of perfectly-competitive firms, a continuum of ex-ante identical and perfectlycompetitive banks, and a monetary authority. The problems of each agent are presented in turn.

\subsection{Households}

Preferences of the representative household are given by

$$
E_{0} \sum_{t=0}^{\infty} \beta^{t} u\left(c_{t}, h_{t}\right),
$$

where $c_{t}$ is a composite consumption good, $h_{t}$ is labor supply, and $\beta \in(0,1)$ is the discount rate. Composite consumption is comprised of a continuum of individual consumption goods indexed by $j \in[0,1]$, which are produced by all firms. It will be made clear below that the sole purpose of considering individual consumption goods is to deliver a flexible and endogenous distinction between cash goods and deposit goods. Once this distinction is made, we only need to track composite consumption $c_{t}$.

The household begins period $t$ with physical capital $k_{t}$, nominal currency $M_{t}$, and nominal deposits $D_{t}$ held at a representative bank. Physical capital is lent directly to firms earning a gross real return $r_{t}$, while deposits earn a gross real return $r_{t}^{D}$. Labor is supplied to firms at the real wage rate $w_{t}$. Both deposits and currency can be used to purchase consumption. As in the standard cash-in-advance model, previously held currency can costlessly purchase

consumption goods. Deposits pay interest, but incur a real usage cost $\gamma$ (e.g. a check-writing cost) for each good purchased.

We now describe how composite consumption gets endogenously separated between cash 
goods and deposit goods. Let composite consumption be given by

$$
c_{t}=\min _{j \in[0,1]}\left(\frac{c_{j t}}{(1-\varepsilon) j^{-\varepsilon}}\right) \text {, }
$$

where $c_{j t}$ denotes the household's consumption of good $j$, and $\varepsilon<0$ represents the elasticity of consumption of good $j$ with respect to the index number $j .^{5}$ This expression delivers the amount of each type- $j$ good for a given amount of total composite consumption

$$
c_{j t}=(1-\varepsilon) j^{-\varepsilon} c_{t}
$$

Equation (3) states that goods with index numbers closer to zero (one) make up a relatively smaller (larger) portion of total consumption. ${ }^{6}$ Since goods with low index numbers are purchased in small quantities, the check-writing cost $\gamma$ is prohibitively high and these goods are therefore purchased with currency. Conversely, goods with high index numbers are purchased in sufficient quantities such that the interest earned on deposits makes it optimal to pay $\gamma$ and purchase these goods with checks. Because $j$ has continuous support, there exists a specific good type where the return from making the purchase with currency or deposits is the same. Denote this good as $j_{t}^{*}$. In what follows, this critical good index becomes a choice of the household and delivers an endogenous separation between cash and deposit goods. ${ }^{7}$ In particular, the use of money balances delivers the conditions

$$
\begin{gathered}
\frac{M_{t}}{P_{t}} \geq \int_{0}^{j_{t}^{*}} c_{j t} d j=j_{t}^{*(1-\varepsilon)} c_{t}, \\
\frac{D_{t}}{P_{t}} \geq \int_{j_{t}^{*}}^{1} c_{j t} d j=\left[1-j_{t}^{*(1-\varepsilon)}\right] c_{t},
\end{gathered}
$$

\footnotetext{
${ }^{5}$ It should be noted that (2) is equivalent to a standard CES-type Armington aggregate of differentiated goods, where the goods are perfect complements and weighted according to their index number $j$. This simplifying expression (with $\varepsilon$ set to -1) was used by Freeman and Kydland (2000) and Dressler and Kersting (forthcoming). Henriksen and Kydland (2010) consider values of $\varepsilon$ between -1.5 and -0.75 .

${ }^{6}$ Note that $(3)$ delivers $\int_{0}^{1} c_{j t} d j=c_{t}$.

${ }^{7}$ Although $j_{t}^{*}$ is simply posited here, it can be derived from a general version of the environment. See the technical appendix for Dressler and Kersting (forthcoming) available on the authors' websites for details.
} 
where $P_{t}$ denotes the price of composite consumption.

The flow budget constraint of the household is given by

$$
w_{t} h_{t}+r_{t} k_{t}+r_{t}^{D} \frac{D_{t}}{P_{t}}+\frac{M_{t}}{P_{t}}+\Theta_{t} \geq c_{t}+\frac{D_{t+1}+M_{t+1}}{P_{t}}+k_{t+1}+\gamma\left(1-j_{t}^{*}\right),
$$

where $\gamma\left(1-j_{t}^{*}\right)$ denotes the total check-writing cost, and $\Theta_{t}$ represents the profit of the banking sector that is returned to the household in lump-sum fashion. ${ }^{8}$ The problem of the representative household is to maximize (1) subject to (4), (5), and (6).

\subsection{Productive Firms}

The representative firm hires labor and capital from households. The firm chooses the degree of capital utilization $\left(\omega_{t}\right)$ which impacts the rate of depreciation according to a convex function $\delta(\omega)$. It is assumed that each firm is required to borrow a fraction $\tau<1$ of its wage bill from the banks at a real lending rate $r_{t}^{L}$. This may, for example, reflect a timing mismatch of cash flows that forces the firms to make payments before production can be sold to households.

The production technology is a CRS function: $y_{t}=f\left(z_{t}, \omega_{t} k_{t}, h_{t}\right)$, where $z_{t}$ denotes exogenous total factor productivity that evolves according to $z_{t}=\kappa_{z}+\rho_{z} z_{t-1}+\varepsilon_{z t}$ with $\varepsilon_{z t} \sim N\left(0, \sigma_{z}^{2}\right)$. Real firm profits are given by

$$
y_{t}+\left[1-\delta\left(\omega_{t}\right)-r_{t}\right] k_{t}-\left[1+\tau\left(r_{t}^{L}-1\right)\right] w_{t} h_{t}
$$

where factor prices and bank rates are taken as given. Note that the loan rate is only assessed on the portion of the wage bill being financed. The representative firm chooses $k_{t}, h_{t}$ and $\omega_{t}$ in order to maximize profits (7). Given the simplicity of the firm's problem, the marginal

\footnotetext{
${ }^{8}$ In the version of the model with an exogenous interest rate paid on reserves, the lump-sun transfer will also include taxes from the monetary authority needed to finance the interest payments.
} 
product of each input is equated with its marginal cost.

$$
\begin{aligned}
\alpha \frac{y_{t}}{k_{t}} & =\left[r_{t}-1+\delta\left(\omega_{t}\right)\right] \\
(1-\alpha) \frac{y_{t}}{h_{t}} & =\left[1+\tau\left(r_{t}^{L}-1\right)\right] w_{t} \\
\alpha \frac{y_{t}}{\omega_{t}} & =\delta^{\prime}\left(\omega_{t}\right) k_{t}
\end{aligned}
$$

\subsection{Financial Intermediaries}

There is a continuum of banks with mass one owned by the households. Each bank draws an idiosyncratic cost $\phi$ from the distribution $F(\phi)$ at the beginning of every period before loans can be given. As stated above, this cost can be interpreted as having to assess the quality of a potential loan, monitoring the borrower, or simply facilitating the loan. Without loss of generality, we index banks by their cost draw $\phi$.

Banks are ex-ante identical and each bank begins the period with the same deposit amount. Bank funding comes from two sources: Households $\left(D_{t}\right)$ and the monetary authority $\left(X_{t}\right)$. The demand for household deposits arises from maximization of expected profit (see below), whereas the monetary transfer is exogenous. After the receipt of deposits, individual banks draw $\phi$ and choose whether or not to make loans to firms. Profit for bank $\phi$ is given by

$$
\left(r_{t}^{L}-\phi\right) L_{t}-r_{t}^{D} D_{t}+\bar{r} Q_{t},
$$

where $L_{t}$ denotes nominal loans, $Q_{t}$ denotes nominal reserves, and $\bar{r}$ is the interest received on reserves. It is assumed that each bank must hold at least a portion $\theta$ of their deposits in the form of reserves

$$
Q_{t} \geq \theta D_{t},
$$

as well as satisfy a simple balance-sheet constraint

$$
D_{t}+X_{t}=L_{t}+Q_{t}
$$


Before stating the optimization problem of bank $\phi$, it is instructive to consider how the cost draw delivers a distinction between banks choosing to hold either loans or excess reserves. First, consider a bank who drew a $\phi_{t}$ high enough such that it would be unprofitable to lend. This bank would choose $L_{t}=0$ and profits would be given by

$$
\left(\bar{r}-r_{t}^{D}\right) D_{t}+\bar{r} X_{t}
$$

Conversely, a bank who drew a $\phi_{t}$ low enough such that it would be profitable to lend would choose $L_{t}=(1-\theta) D_{t}+X_{t}$ and profits would be given by

$$
\left[(1-\theta)\left(r_{t}^{L}-\phi_{t}\right)+\theta \bar{r}-r_{t}^{D}\right] D_{t}+\left(r_{t}^{L}-\phi_{t}\right) X_{t}
$$

Since $\phi$ has continuous support and all banks take rates of return as given, there exists a critical cost $\phi_{t}^{*}$ such that bank $\phi^{*}$ is indifferent between holding loans or excess reserves because they offer the same return. Equating (14) and (15) at $\phi_{t}=\phi_{t}^{*}$ results in

$$
\phi_{t}^{*}=r_{t}^{L}-\bar{r},
$$

which simply equates the net returns of the two assets the bank can choose to hold.

We assume that $\phi$ is drawn from a Pareto distribution defined over the interval $\left[\phi_{m}, \infty\right)$ with cumulative distribution function $F(\phi)=1-\left(\frac{\phi_{m}}{\phi}\right)^{\sigma}$, where $\sigma>1$ determines the dispersion of the distribution. Taking $\phi^{*}$ as given, the real, ex-ante profit for each bank is given by

$$
\begin{aligned}
\Theta_{t}= & \int_{\phi_{m}}^{\phi^{*}}\left[\left[(1-\theta)\left(r_{t}^{L}-\phi_{t}\right)+\theta \bar{r}-r_{t}^{D}\right] D_{t}+\left(r_{t}^{L}-\phi_{t}\right) X_{t}\right] P_{t}^{-1} \partial F(\phi)+\ldots \\
& \int_{\phi^{*}}^{\infty}\left[\left(\bar{r}-r_{t}^{D}\right) D_{t}+\bar{r} X_{t}\right] P_{t}^{-1} \partial F(\phi) .
\end{aligned}
$$

Demand for deposits is derived from the banks maximizing ex-ante profits with respect to 
$D_{t}$, taking interest rates, the distribution of $\phi$, and the monetary transfer as given. The first order condition is given by

$$
\begin{aligned}
r_{t}^{D}= & (1-\theta)\left[r_{t}^{L}\left[1-\left(\frac{\phi_{m}}{\phi^{*}}\right)^{\sigma}\right]-\frac{\sigma \phi_{m}}{\sigma-1}\left[1-\left(\frac{\phi_{m}}{\phi^{*}}\right)^{\sigma-1}\right]\right]+\ldots \\
& \bar{r}\left[\theta+(1-\theta)\left(\frac{\phi_{m}}{\phi^{*}}\right)^{\sigma}\right]
\end{aligned}
$$

To clarify intuition on (18), it is helpful to look at two limiting cases.

$$
\begin{aligned}
\lim _{\phi^{*} \rightarrow \phi_{m}} r_{t}^{D} & =\bar{r} \\
\lim _{\phi^{*} \rightarrow \infty} r_{t}^{D} & =(1-\theta)\left(r_{t}^{L}-\frac{\sigma}{\sigma-1} \phi_{m}\right)+\theta \bar{r}
\end{aligned}
$$

If the critical value of $\phi^{*}$ approaches $\phi_{m}$, no bank would be willing to make loans in the limit. In this case, the deposit rate must equal the interest rate paid on reserves for an interior solution to exist. If the critical value approaches infinity, all banks will enter the loan market. In this case, the deposit rate equals the weighted average of the loan rate (net of average costs) and the reserve rate. Note that the net lending rate here is simply the gross lending rate less the average cost given by the Pareto distribution. If $\phi_{m}=0$, then this deposit rate would be the same rate suggested by a model where all banks are active and hold minimal reserves.

\subsection{The Monetary Authority}

The budget constraint of the monetary authority is $X_{t}=M_{t+1}^{T}-M_{t}^{T}$, where $M_{t+1}^{T}$ denotes the aggregate stock of currency and deposits available at the end of period $t$. The currency base evolves according to $M_{t+1}^{T}=\mu_{t} M_{t}^{T}$, where $\mu_{t}$ denotes the gross growth rate. Monetary policy is assumed to be conducted exogenously so that money growth evolves according to $\mu_{t}=\kappa_{\mu}+\rho_{\mu} \mu_{t-1}+\varepsilon_{\mu t}$ with $\varepsilon_{\mu t} \sim N\left(0, \sigma_{\mu}^{2}\right)$. The transfer $X_{t}$ is given to the banks as described above. 


\subsection{Equilibrium}

The model is closed by stating the various market clearing conditions. The goods market clearing condition states that all output must be consumed, invested in new capital creation, or used to pay the real costs of check-writing and loan facilitation.

$$
\begin{aligned}
y_{t}= & c_{t}+k_{t+1}-\left[1-\delta\left(\omega_{t}\right)\right] k_{t}+\gamma\left(1-j_{t}^{*}\right)+\ldots \\
& {\left[(1-\theta) D_{t}+X_{t}\right] P_{t}^{-1}\left(\frac{\sigma \phi_{m}}{\sigma-1}\right)\left[1-\left(\frac{\phi_{m}}{\phi^{*}}\right)^{\sigma-1}\right] }
\end{aligned}
$$

The money market clearing condition states that all available currency at the beginning of the period is either in the form of currency in the hands of the public or as checkable deposits.

$$
M_{t}^{T}=M_{t}+D_{t}
$$

Finally, the loan market clearing condition states that all available loans must satisfy the portion of the firms' wage bills in need of financing,

$$
\tau w_{t} h_{t}=\left[(1-\theta) D_{t}+X_{t}\right] P_{t}^{-1}\left[1-\left(\frac{\phi_{m}}{\phi^{*}}\right)^{\sigma}\right]
$$

where the right-hand side denotes aggregate real lending.

The decision rules and pricing functions can be defined as functions of $k_{t}, M_{t}, D_{t}, \mu_{t}$, and $z_{t}$. Therefore, for all $\left\{k_{t}, M_{t}, D_{t}, \mu_{t}, z_{t}\right\}$, an equilibrium is defined as a list of prices $\left\{P_{t}\right.$, $\left.r_{t}, r_{t}^{D}, r_{t}^{L}, w_{t}\right\}$ and allocations $\left\{k_{t+1}, M_{t+1}, D_{t+1}, h_{t}, c_{t}, j_{t}^{*}, \phi_{t}^{*}\right\}$ such that: (i) households maximize (1) subject to (4), (5), and (6), (ii) firms maximize profits (7), (iii) banks maximize ex-ante profits (17), and (iv) the markets for goods, money, and loans clear. 


\subsection{Discussion}

Before turning to the quantitative analysis of the model, it is informative to briefly touch upon the relationship between loan activity and real output which is central to how excess reserves can influence the predictions of the model. Combining the firm's optimal labor demand (9) with the loan market clearing condition (21) and linearizing yields

$$
\hat{y}_{t}=\hat{l}_{t}+\left[\frac{l r^{L}}{(1-\alpha) y}\right] \hat{r}_{t}^{L},
$$

where $l$ denotes real loans, a caret above a variable denotes its deviation from steady state, and variables without time subscripts are fixed at their steady state values. Note that the two equations used to arrive at (22) are shared by traditional limited participation models and are therefore useful for comparing versions of the model with and without excess reserves. First, consider a model with no excess reserves because all banks are currently holding as many loans as possible. A monetary contraction in this economy results in an immediate decline in lending and an increase in the lending rate due to the decline in loan supply (i.e. $\hat{l}_{t}<0$ and $\left.\hat{r}_{t}^{L}>0\right)$. The standard prediction of a monetary contraction in these models is that the decline in lending overcomes the increase in the lending rate resulting in a decline in real output. In our model, equation (22) becomes slightly more sophisticated due to equation (16) which shows that an increase in the real lending rate will induce passive banks to become active and begin lending their reserves.

$$
\hat{\phi}_{t}^{*}=\frac{r^{L}}{\phi^{*}} \hat{r}_{t}^{L}
$$

These passive banks becoming active are precisely the extensive margin in effect. Any increase in lending due to the extensive margin will mute the decrease due to the intensive margin brought about by the monetary contraction. In some of our quantitative experiments below, we show that the extensive margin can overcome the intensive margin resulting in 
increases in real lending and real output in response to a monetary contraction.

\section{Quantitative Analysis}

\subsection{Functional Forms and Calibration}

The functional forms and parameter values are determined following the business-cycle literature (e.g. Cooley and Hansen, 1989) and so the resulting steady state of the model matches particular long-run properties of the US economy.

A period is one quarter. The discount parameter $\beta$ is calibrated so that the annual real interest rate is 4 percent. The corporate bond to prime lending rate ratio serves to link the lending rate of capital $(r)$ to bank loans $\left(r^{L}\right)$. The average annual lending rate in post-war US data prior to 2008 is roughly 20 basis points higher than the annual corporate bond rate. This difference is negligible at the quarterly frequency and the ratio in the model is set to one. The money growth rate $(\mu-1)$ is set to 3 percent annually, and persistence of money growth shocks $\left(\rho_{\mu}\right)$ is set to 0.35 , similar to Christiano (1991) and Fuerst (1992). The gross rate of return on reserves $(\bar{r})$ is set to one, and the minimum reserve requirement $(\theta)$ is set to 0.10 .

Steady state output is normalized to one, and the capital stock to annual output ratio is 2.5. The production function is assumed to be $y=z(\omega k)^{\alpha} h^{1-\alpha}$, and $\alpha$ is calibrated to make labor's share of national income roughly two-thirds. The effect of endogenous capital utilization on the depreciation rate follows Greenwood et al. (1988) and is assumed to be $\delta(\omega)=b \omega^{\psi} / \psi$. The parameters $b$ and $\psi$ are calibrated so that steady state capital utilization is 80 percent and $\delta(\omega)$ equals 10 percent annually. The persistence of technology shocks $\left(\rho_{z}\right)$ is set to 0.95 as in Prescott (1986).

The utility function is assumed to be $\left(c^{\eta}(1-h)^{1-\eta}\right)^{1-V} /(1-V)$. The parameter $\eta$ is calibrated such that a household's average allocation of time to market activity (net of sleep and personal care) is one-third which is in line with estimates of Ghez and Becker (1975). 
$V$ is set to 2 which is within the range reported by Neely et al. (2001). We set $\varepsilon=-1$ so that the trade-off between quantities of cash and deposit goods is the same as Freeman and Kydland (2000).

The four remaining parameters define the costs of banking $\left(\phi_{m}\right.$ and $\left.\sigma\right)$, the demand for loans $(\tau)$, and the check-writing cost $(\gamma)$. We follow a two-step calibration procedure in order to make the different versions of our model as comparable as possible. First, we calibrate $\gamma$ and $\tau$ using a version of our model with no loan facilitation costs, so all banks are active and hold minimal reserves. We calibrate $\gamma$ so the steady state deposit-currency ratio is 0.75 . This ratio is taken from averaging the demand deposits divided by cash in the hands of the public over the post-war US data. Taking this deposit-currency ratio as given, the loan market clearing condition of the model delivers $\tau=0.4523 .{ }^{9}$ Note that the calibration results in slightly over 45 percent of a firm's wage bill needing to be financed with bank loans, which corresponds to a real loan to output ratio of 0.2974 . The final step in our calibration involves determining $\phi_{m}$ and $\sigma$ for versions of the model displaying excess reserves in the banking sector. We choose the curvature parameter on the Pareto distribution $(\sigma)$ to be 2 and keep it fixed across all versions. The parameter $\phi_{m}$ is determined independently for each version of our model by setting total-required (TR) reserve ratios above one. The ratio values we selected for our quantitative experiments are $T R=\{1.04,1.73,2.00,4.00\}$. The first value is taken from the pre-financial crisis data, while the other three sufficiently show the range of dynamic responses from our model. In order to determine $\phi_{m}$ for each of the models, we decided to vary the deposit-currency ratio across models so $\tau$ as well as the loan-output ratio can remain fixed. The reason behind this procedure is that the steady state loan-output ratio appears in (22) and we did not want the output dynamics across versions of our model to be influenced by changes in steady state values or how much the firms need to finance $(\tau)$.

\footnotetext{
${ }^{9}$ While the particular choice of demand deposits in the calibrating ratio appears straight-forward given that deposits in the model are solely used for consumption purchases, the choice of currency in the hands of the public may be inaccurate given the large amount of cash held outside of the US. We have experimented with larger values for this ratio, and the only result is a larger value of $\tau$. The quantitative results presented below are insensitive to the value of this ratio.
} 
Therefore, determining different TR ratios while keeping the real-loan to output ratio intact is sufficient to determine a $\phi_{m}$ and deposit-currency ratio for each model. All calibrated parameter values are summarized in Table 1.

\subsection{Baseline Model versus Small Excess Reserves}

We begin detailing the predictions of our baseline model without excess reserves (by assumption), and comparing them to a model with a steady state total-required reserve ratio of 1.04. The impulse responses to a 1 percent monetary contraction in period 1 are illustrated in Figure 1.

The solid lines in the figure show many similarities between the baseline model and the standard limited participation framework. A monetary contraction delivers a decrease in real loan supply, which leads to an increase in the effective wage rate due to an increase in the real lending rate. ${ }^{10}$ The increase in the effective wage decreases labor demand, the utilization rate of the existing capital stock, and real output. The slower depreciation rate due to lower capital utilization delivers the decrease in investment, the increase in consumption, and the decrease in the price level. In the period following the shock, the household is able to alter her currency and deposit balances as well as the portion of consumption purchased with each of these balances $\left(j_{t}^{*}\right)$ in order to take advantage of the higher deposit rates. The increase in deposits begins to offset the monetary contraction in the prior period, and these series of responses deliver the traditional path of nominal interest rates. The nominal interest rate first rises displaying a liquidity effect and then falls below its steady state value displaying the expected inflation effect.

The dashed lines in the figure illustrate how adding a slight amount of steady state excess reserves can preserve the qualitative predictions of the model while making slight changes to the magnitudes. Compared to the baseline model, this version has a small portion of banks choosing to be inactive prior to the monetary contraction. Some of these banks choose to

\footnotetext{
${ }^{10}$ The effective wage (rate is the wages firms need to pay due to) is the total cost of one unit of labor including financing costs: $w_{t}\left[1+\tau\left(r_{t}^{L}-1\right)\right]$.
} 
become active and lend their reserves after a monetary contraction, resulting in real loans decreasing by a smaller amount than in the baseline case. The smaller decline in real loan supply results in a smaller increase in the real lending rate, and combined with a similar path of the price level as in the baseline case, further results in a muted liquidity effect. In the period after the shock, households adjust their currency and deposit balances as in the baseline case, and banks who chose to become active as a result of the monetary shock begin to return to inactive status. It should be noted that the slightly larger decrease in output and some other real variables relative to the baseline version can be explained by equation (22). Recall that output moves in the same direction as real lending and the lending rate. Mechanically, the larger increase in the real lending rate in the baseline model (due to the absence of an extensive margin) ends up lessening the decline in output. The extensive margin delivers a smaller decline in real lending and a smaller increase in the lending rate relative to the baseline model. Given our calibration, the latter effect outweighs the former leading to a slightly larger fall in output. Nonetheless, this comparison establishes that even if the amount of excess reserves in the environment is small, there is still the potential of the extensive margin of lending to dampen the ability of monetary policy to induce a sizeable liquidity effect.

\subsection{Various Excess Reserve Levels}

We now turn our attention to various levels of excess reserves in the environment and their influence on the model dynamics. Figures 2 and 3 illustrate the predictions of the model to a one percent monetary contraction and positive productivity shock, respectively.

We begin with the effects of a monetary contraction. Only the key variables which differ from the baseline case are illustrated in Figure 2. The TR ratios 1.73, 2.0, and 4.0 correspond to the banking sector holding $7.3,10$, and 30 percent excess reserves in steady state, respectively. The solid line indicates the response of the model with $T R=1.73$. This particular total to required reserve ratio was chosen because the increase in real lending due 
to the extensive margin perfectly offsets the decrease in real lending due to the intensive margin. Although there is no change in real lending, the real interest rate increases to induce the inactive banks to become active. According to equation (22), this increase in the real lending rate results in a rise in output due to the increase in labor demand and the utilization rate of the capital stock. Since the increase in the real lending rate is smaller than in the two cases considered in Figure 1, it is clear that the liquidity effect should also be smaller. In fact, the liquidity effect for this excess reserve level disappears and the nominal interest rate declines immediately after a monetary contraction. In the period following the monetary contraction, households choose to hold more deposits which further increases real lending, reduces the effective wage, and raises real output. The remaining TR ratios considered show that the larger the amount of excess reserves in the economy, the larger the potential extensive margin of lending. In these cases, the increase in lending due to the extensive margin actually exceeds the decrease in lending due to the intensive margin. This boost in real lending provides a further increase in real output.

We now turn our attention to Figure 3 which compares the predictions of the model with $T R=4.0$ to the baseline version $(T R=0)$ in response to a 1 percent productivity increase. It is straight-forward to explain that the existence of an extensive margin to lending provides a degree of output amplification relative to the baseline environment. In the baseline case, since all banks are currently active and holding minimal reserves, they simply cannot increase their lending to firms in the event of a productivity innovation. Therefore, the increase in demand for labor is dampened by an increase in the financing costs to firms. When there exists a portion of the banking sector holding excess reserves at the time of the shock, they can choose to become active and provide the additional financing demanded by firms. This reduces the increase in financing costs to firms which results in a larger response in output. Quantitatively speaking, the figure illustrates that a model with 30 percent excess reserves amplifies the output response by over 35 percent relative to the baseline model. Experimentation with other TR ratios suggest that the amount of 
excess reserves in the banking sector are directly correlated to the magnitude of output amplification. This result draws attention to the fact that excess reserves do not only have the potential to flood the economy with inflationary credit, which is what commentators frequently focus on. In addition, excess reserves also represent real resources that can be quickly allocated to beneficial uses in the event of an economic upturn.

We conclude this section with a brief discussion on the robustness of our model predictions with respect to our calibration. First, the qualitative predictions of our model are completely insensitive to our choice of the deposit-currency ratio which was used to calibrate the amount of financing needed by firms. A larger amount of steady state deposits relative to currency results in a larger loan supply and therefore a larger $\tau$ which is needed to clear the loan market. Although the steady state level of lending appears in (22), experimentation with various deposit-currency ratios resulted in little quantitative changes to our model. The largest quantitative changes to our model were observed when we altered the curvature of the Pareto distribution $(\sigma)$. A comparison between our conservative choice of 2 and two larger parameter values are illustrated in Figure 4 for a 1 percent monetary contraction in the model with $T R=2.0$. As the figure indicates, a larger degree of curvature results in an amplification of the predictions discussed above. This is due to the larger mass of banks with similar loan facilitation costs near the critical cut-off value $\left(\phi^{*}\right)$. Therefore, an equally-sized shock results in more banks becoming active and an amplified response. Nonetheless, all of the qualitative predictions of the model are preserved.

\subsection{Paying Interest on Reserves}

We now turn to an exercise which assesses the short-run impact of an increase in the interest rate paid to bank reserves similar to the Federal Reserve policy maintained since October 6, 2008. This requires making the parameter $\bar{r}$ in the model an exogenous variable which is assumed to evolve according to $\bar{r}_{t}=\kappa_{r}+\rho_{r} \bar{r}_{t-1}+\varepsilon_{r t}$ with $\varepsilon_{r t} \sim N\left(0, \sigma_{r}^{2}\right)$. Since the current policy is viewed as a persistent increase in the interest rate, we chose $\rho_{r}=0.99$ and 
examined the response of the model to a 25 basis point increase in the annual interest rate on reserves. ${ }^{11}$ The response of the model is illustrated in Figure 5 for the three larger values of the TR ratio considered above.

As the figure indicates, an increase in the interest rate paid on reserves induces more banks to become inactive and hold excess reserves. This action reduces the real loan supply, increases the effective wage to firms, and decreases labor demand and real output. While these responses are straight-forward, it should be noted that the significant impact of the interest rate shock occurs in the following period when households are allowed to adjust their deposit balances. In particular, the slight decrease in real loans increases the real lending rate in the period of the shock. In the following period, households shift more of their money into deposits since this becomes more attractive than holding currency. The increase in loanable funds places downward pressure on the real loan rate, making it even less attractive for banks to actively lend to firms. Therefore, banks accept the deposits from households in the period after the shock, and then a larger portion of banks choose to be inactive. Another interesting feature is that the size of the response in the period after the shock is directly related to the amount of excess reserves in the banking sector prior to the shock. For example, when the banking sector has 30 percent excess reserves $(\mathrm{TR}=4.00)$ relative to 7.3 percent $(\mathrm{TR}=1.73)$, the decrease in output in the period of the shock is roughly identical (-0.02 percent) while the decrease in output in the model with more excess reserves is more than an order of magnitude larger in the period after the shock $(-1.8$ percent versus -0.15 percent). The technical explanation behind these results lies in the fact that a higher initial amount of excess reserve holdings in the banking sector places the critical cutoff $\phi^{*}$ on a steeper portion of the distribution. Therefore, when excess reserves are initially higher, even fewer banks find it optimal to continue to lend once households increase their level of deposits. The result becomes more intuitive if we consider a correlation between the level of excess reserves and the level of efficiency in the banking sector. A large amount of excess

\footnotetext{
${ }^{11}$ The gross quarterly interest rate on reserves in our model is therefore 1.0006 .
} 
reserves implies that a large portion of the banks find it too costly to evaluate, monitor, or facilitate lending. Therefore, small shocks to the banking sector can lead to large swings in banking sector activity. This result complements findings by Ireland (2012), who concludes that the short-run effects of paying interest on reserves can be large when the banking sector is inefficient.

\section{Conclusion}

This paper establishes and analyzes a DSGE environment where banks choose between actively lending to firms or passively holding excess reserves. The ability of banks to hold excess reserves activates an extensive margin of loan supply which is shown to offset the intensive margin of loan supply traditionally observed in models which assume all banks actively lend and hold minimal reserves. The results of our model suggest that excess

reserves in the banking sector can dampen and even overcome the standard liquidity effect of monetary contractions, amplify the output response to productivity shocks, and bring about large, short-run responses to an exogenous increase in the interest rate paid on reserves.

The results of our model paint a rather optimistic situation for the Federal Reserve once they begin to undo the policies enacted to fight the recent financial crisis. There will almost certainly be levels of excess reserves in the banking sector when the Federal Reserve ceases its policy of paying interest on reserves and begins increasing the Federal Funds rate through open market operations. The predictions of our model suggest that monetary contractions could actually lead to increases in output while still having the desired downward effect on the price level. In addition, ceasing to pay interest on reserves will lead to an additional increase in output. While the magnitudes of these effects depend upon the initial amount of excess reserves in the banking system, we have shown that the positive impacts of these policies can be large with amounts of excess reserves that are much smaller than those currently observed in the data. 
This optimistic picture for the Federal Reserve described by our model should nevertheless be taken with caution. Our model abstracts from any risk on the side of the firm and assumes that there is no default. Our model also assumes that all loans are productive and households do not hold any debt. We thus consider the analysis in the present paper to be a first step in analyzing the mechanism which induces banks to hold excess reserves in equilibrium. Model features such as loan risk, household debt, and even indeterminacy due to economies of scale in loan facilitation are all highly relevant issues that are left to future research.

\section{References}

[1] Bartolini L., Bertola, G. and Prati, A., "Banks' Reserve Management, Transaction Costs, and the Timing of Federal Reserve Intervention" Journal of Banking \& Finance 25(7) (July 2001), 1287-1317.

[2] Berentsen, A. and Monnet, C., "Monetary Policy in a Channel System," Journal of Monetary Economics 55(6) (September 2008), 1067-1080.

[3] Bernanke, B.S., Gertler, M. and Gilchrist, S. "The Financial Accelerator in a Quantitative Business Cycle Framework" In: John B. Taylor and Michael Woodford (ed.), Handbook of Macroeconomics, (1999), Volume 1, Chapter 21, Part C, Pages 1341-1393.

[4] Carlstrom C.T. and Fuerst, T.S., "Agency Costs, Net Worth, and Business Fluctuations: A Computable General Equilibrium Analysis," American Economic Review 87(5) (December 1997), 893-910.

[5] Chari, V.V., Christiano, L.J., and Eichenbaum, M., "Inside Money, Outside Money, and Short-Term Interest Rates," Journal of Money, Credit and Banking 27(4) (November 1995), 1354-1386.

[6] Christiano, L.J., "Modeling the Liquidity Effect of a Monetary Shock," Federal Reserve Bank of Minneapolis Quarterly Review 15(1) (Winter 1991), 3-34. 
[7] Clouse, J.A. and Dow Jr., J.P., "A Computational Model of Banks' Optimal Reserve Management Policy" Journal of Economic Dynamics and Control 26(11) (September 2002), 1787-1814.

[8] Cooley, T.F. and Hansen, G.D., "The Inflation Tax in a Real Business Cycle Model," American Economic Review 79(4) (September 1989), 733-748.

[9] Diaz-Gimenez, J., Prescott, E.C., Fitzgerald, T., and Alvarez, F., "Banking in Computable General Equilibrium Models," Journal of Economic Dynamics and Control 16(34) (July-October 1992), 533-339.

[10] Dressler, S.J. and Kersting, E.K., "Economies of Scale in Banking, Indeterminacy, and Business Cycles," Macroeconomic Dynamics (forthcoming).

[11] Ennis, H.M. and Weinberg, J.A., "Interest on Reserves and Daylight Credit," FRB Richmond Economic Quarterly 93(2) (Spring 2007), 111-142.

[12] Freeman, S. and Kydland, F.E., "Monetary Aggregates and Output," American Economic Review 90(5) (December 2000), 1125-1135.

[13] Fuerst, T.S., "Liquidity, Loanable Funds, and Real Activity," Journal of Monetary Economics 29(1) (February 1992), 3-24.

[14] Gertler, M. and Kiyotaki, N. "Financial Intermediation and Credit Policy in Business Cycle Analysis", in: Benjamin M. Friedman and Michael Woodford (ed.), Handbook of Monetary Economics, (2010), edition 1, volume 3, chapter 11, pages 547-599.

[15] Gertler, M., Kiyotaki, N., and Queralto, A., "Financial Crises, Bank Risk Exposure and Government Financial Policy," Journal of Monetary Economics, 59(S) (2012), S17-S34.

[16] Ghez, G.R. and Becker, G.S., The Allocation of Time and Goods over the Life Cycle, (New York: Columbia University Press, 1975). 
[17] Goodfriend, M., "Monetary Policy in the New Neoclassical Synthesis: A Primer," International Finance 5(2) (Summer 2002), 165-191.

[18] Greenwood, J., Hercowitz, Z., and Huffman, G.W., "Investment, Capacity Utilization, and the Business Cycle," American Economic Review 78(3) (June 1988), 402-417.

[19] Henriksen, E. and Kydland, F.E., "Endogenous Money, Inflation and Welfare," Review of Economic Dynamics 13(2) (April 2010), 470-486.

[20] Hopenhayn, H. "Entry, Exit, and Firm Dynamics in Long Run Equilibrium," Econometrica 60 (1992), 1127-1150.

[21] Ireland, P., "The Macroeconomic Effects of Interest on Reserves," NBER working paper no. 18409 (September 2012).

[22] Keister, T., Martin, A. and McAndrews, J., "Divorcing Money from Monetary Policy," Economic Policy Review, Federal Reserve Bank of New York (September 2008), 41-56.

[23] Keister, T. and McAndrews, J., "Why are Banks Holding so Many Excess Reserves?" Current Issues in Economics and Finance 15(8) (December 2009), 1-10.

[24] Neely, C.J., Roy, A. and Whiteman, C.H., "Identification Failure in the Intertemporal Consumption CAPM," Journal of Business and Economic Statistics 19 (October 2001), $395-403$.

[25] Porter, R.D. and Judson, R.A., "The Location of US Currency: How Much is Abroad?" Federal Reserve Bulletin 82(10) (1996), 883-903.

[26] Prescott, E.C., "Theory Ahead of Business Cycle Measurement." Federal Reserve Bank of Minneapolis Quarterly Review (Fall 1986), 9-22.

[27] Sargent, T. and Wallace, N., "Interest on Reserves," Journal of Monetary Economics 15(3), (May 1985), 279-290. 
[28] Smith, B., "Interest on Reserves and Sunspot Equilibria: Friedman's Proposal Reconsidered," Review of Economic Studies, 58(1), (January 1991), 93-105.

[29] Sannikov, Y. and Brunnermeier, M. K."A Macroeconomic Model with a Financial Sector" (2012) No 507, 2012 Meeting Papers, Society for Economic Dynamics.

[30] Thornton, D.L. "The Relationship between the Daily and Policy-Relevant Liquidity," Review (January 2010), Federal Reserve Bank of St. Louis, 73-88. 


\section{Tables and Figures}

Table 1: Calibrated Parameter Values

\begin{tabular}{llc}
\hline \hline Symbol & Description & Value(s) \\
\hline$\alpha$ & capital share & 0.3397 \\
$\beta$ & discount factor & 0.9902 \\
$b$ & depreciation level & 0.0465 \\
$\psi$ & depreciation curvature & 1.4086 \\
$\eta$ & consumption share & 0.3683 \\
$V$ & risk aversion & 2 \\
$\varepsilon$ & consumption curvature & -1 \\
$\rho_{z}$ & AR coefficient $(z)$ & 0.95 \\
$\rho_{\mu}$ & AR coefficient $(\mu)$ & 0.35 \\
$\theta$ & reserve requirement & 0.10 \\
$\sigma$ & curvature parameter & 2 \\
$\tau$ & loan demand & 0.4523 \\
$\gamma$ & check-clearing cost $^{a}$ & $\{0.0101,0.0088,0.0050,0.0043,0.0014\}$ \\
$\phi_{m}$ & minimum cost & \\
\hline Note: & ${ }^{a}$ The different values respectively corespond to TR values $\{1.00,1.04,1.73,2.00,4.00\}$ \\
\hline \hline
\end{tabular}



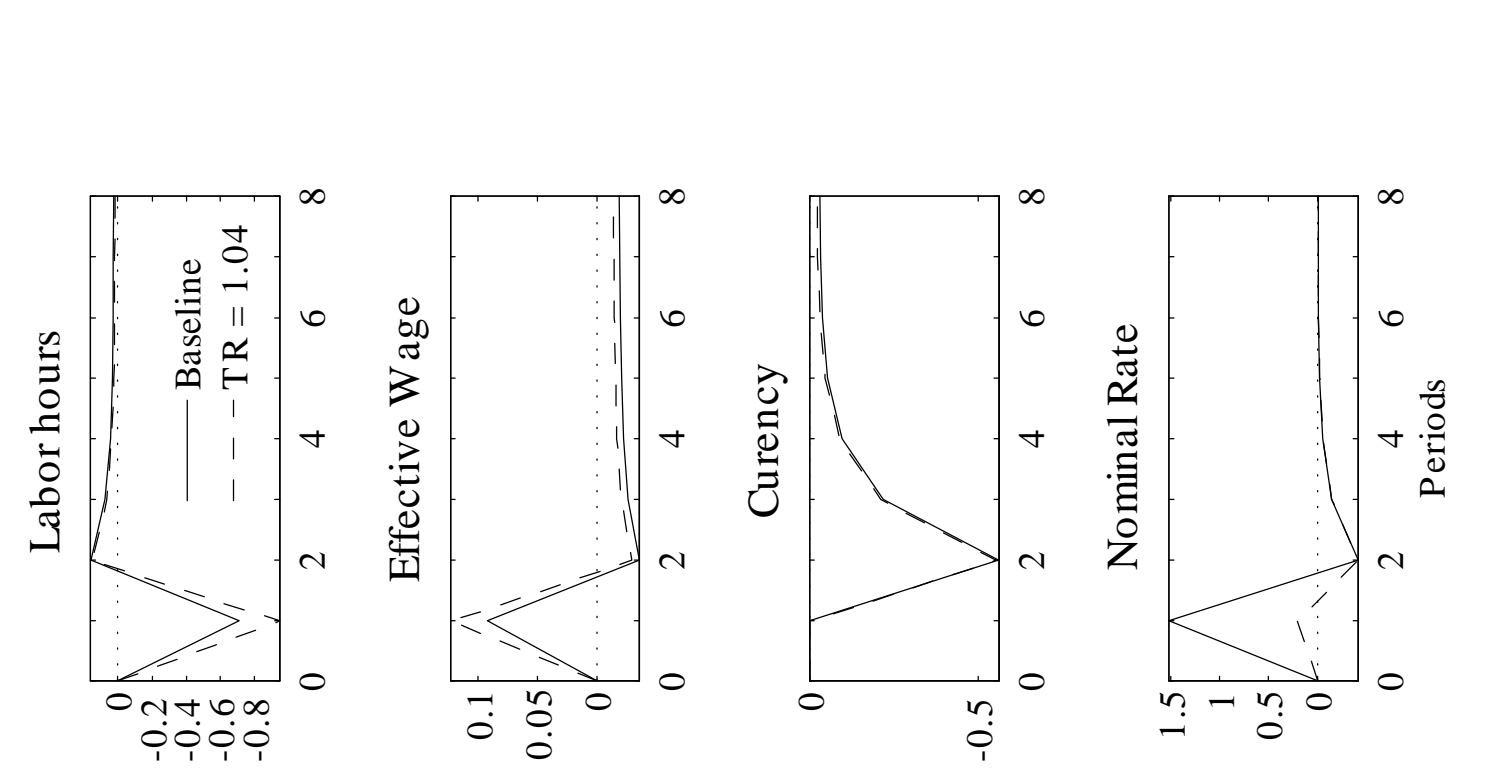

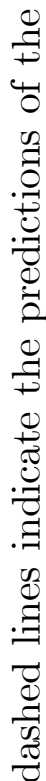
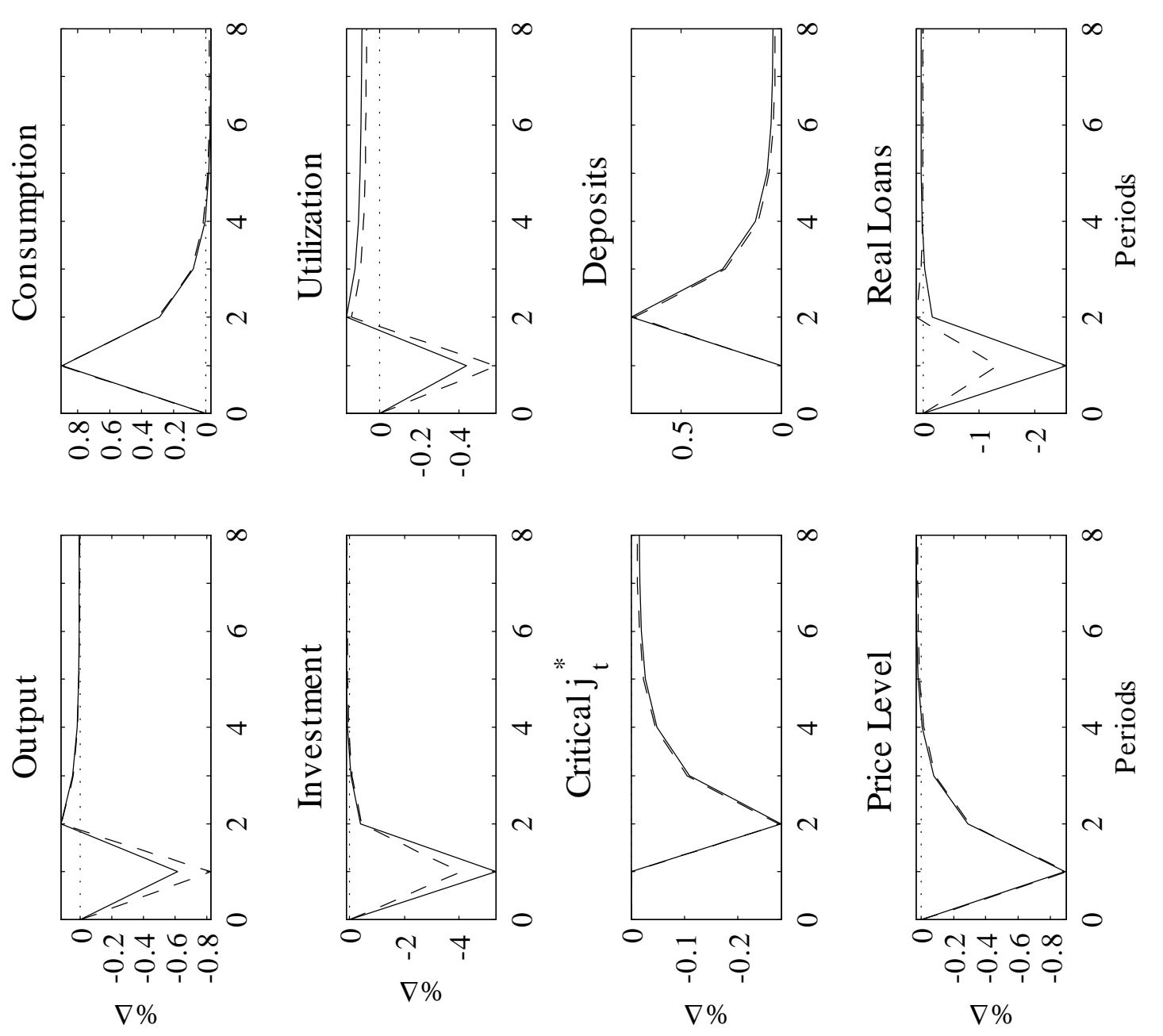

تี

:

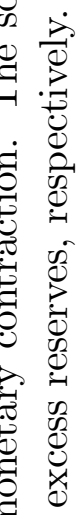

$\nabla \%$

$\nabla \%$ 

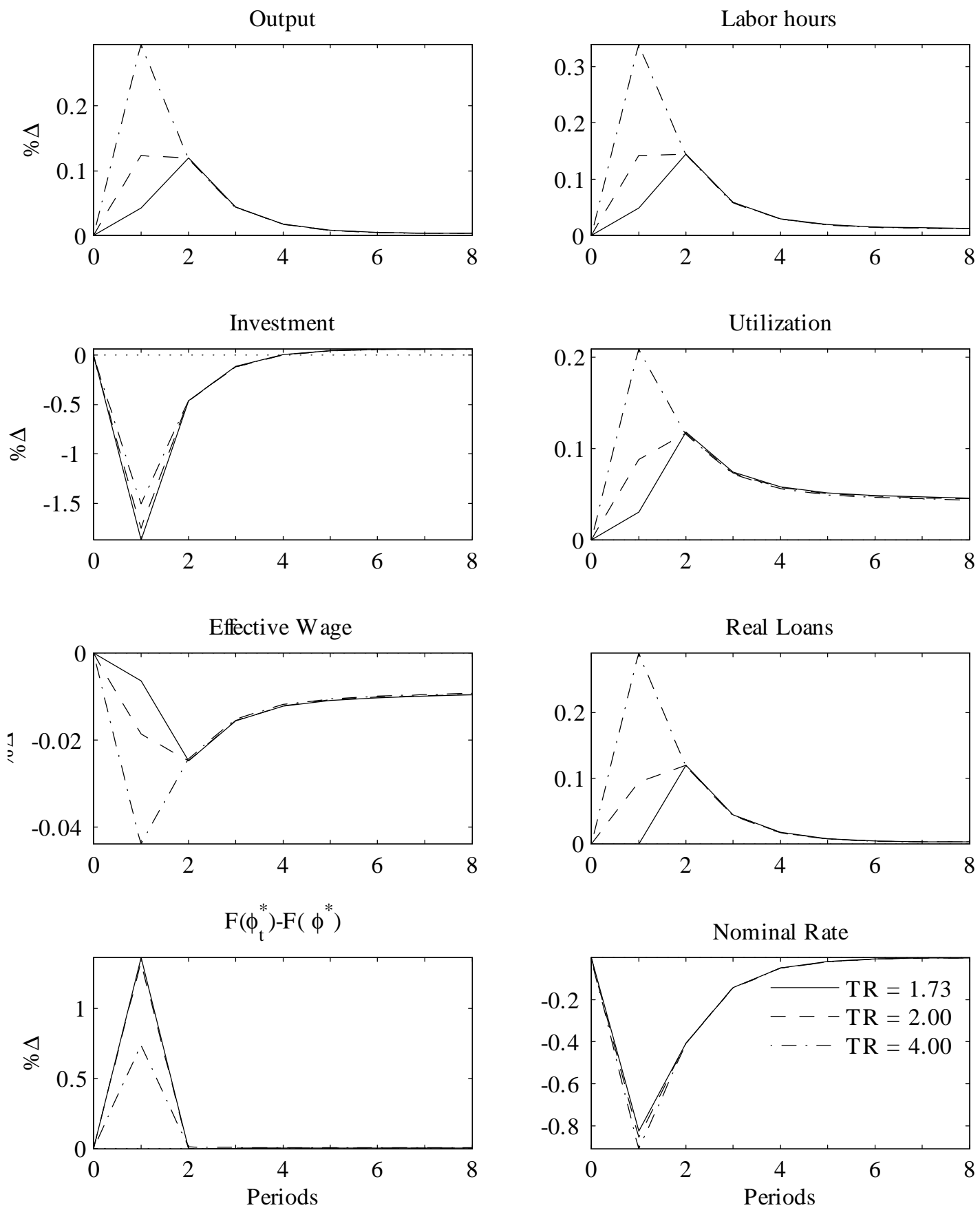

Figure 2: Impulse responses to a 1 percent monetary contraction. The lines indicate the predictions of the model with $7.3,10.0$, and 30.0 percent steady state excess reserves, respectively. 


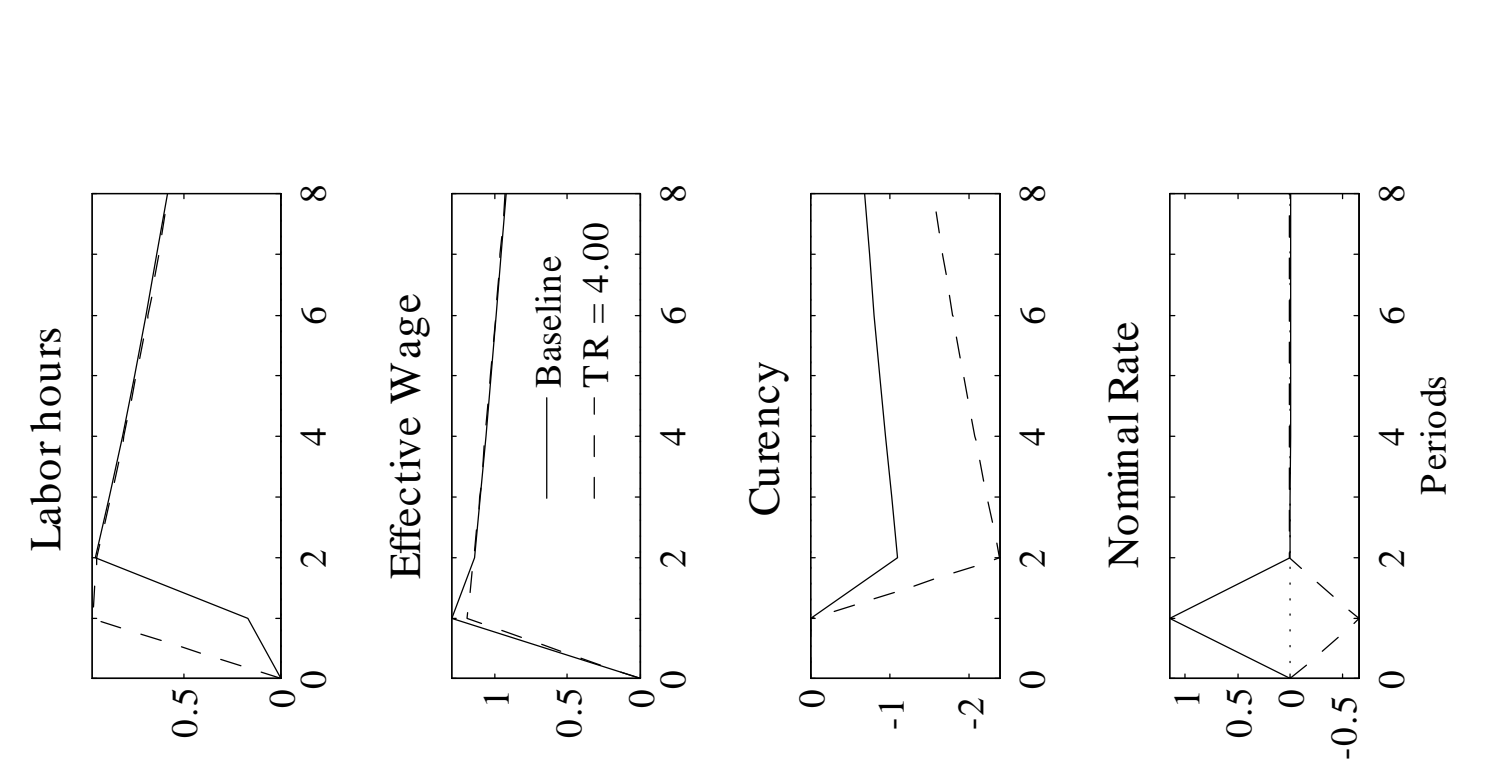

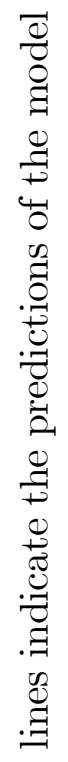
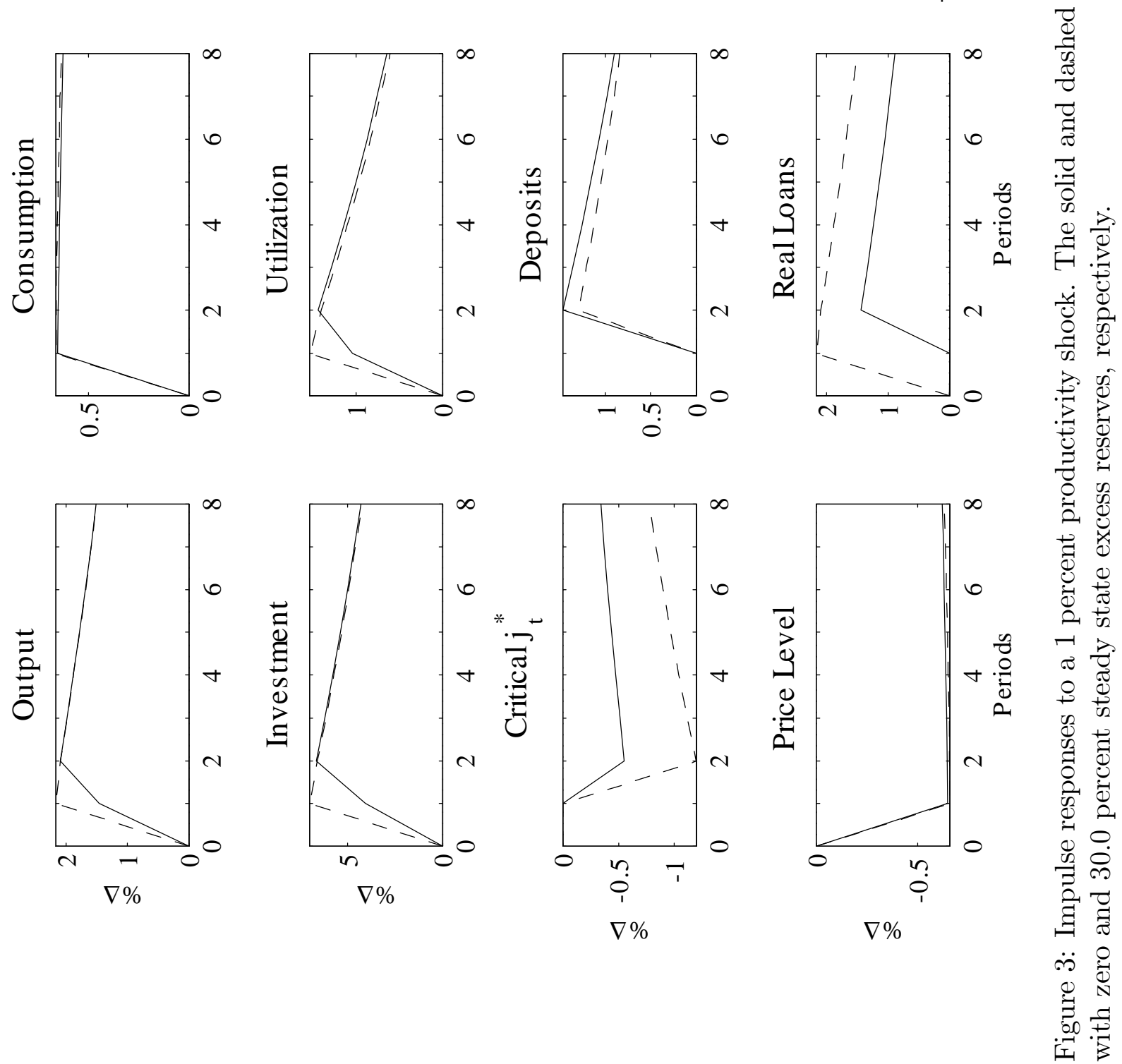

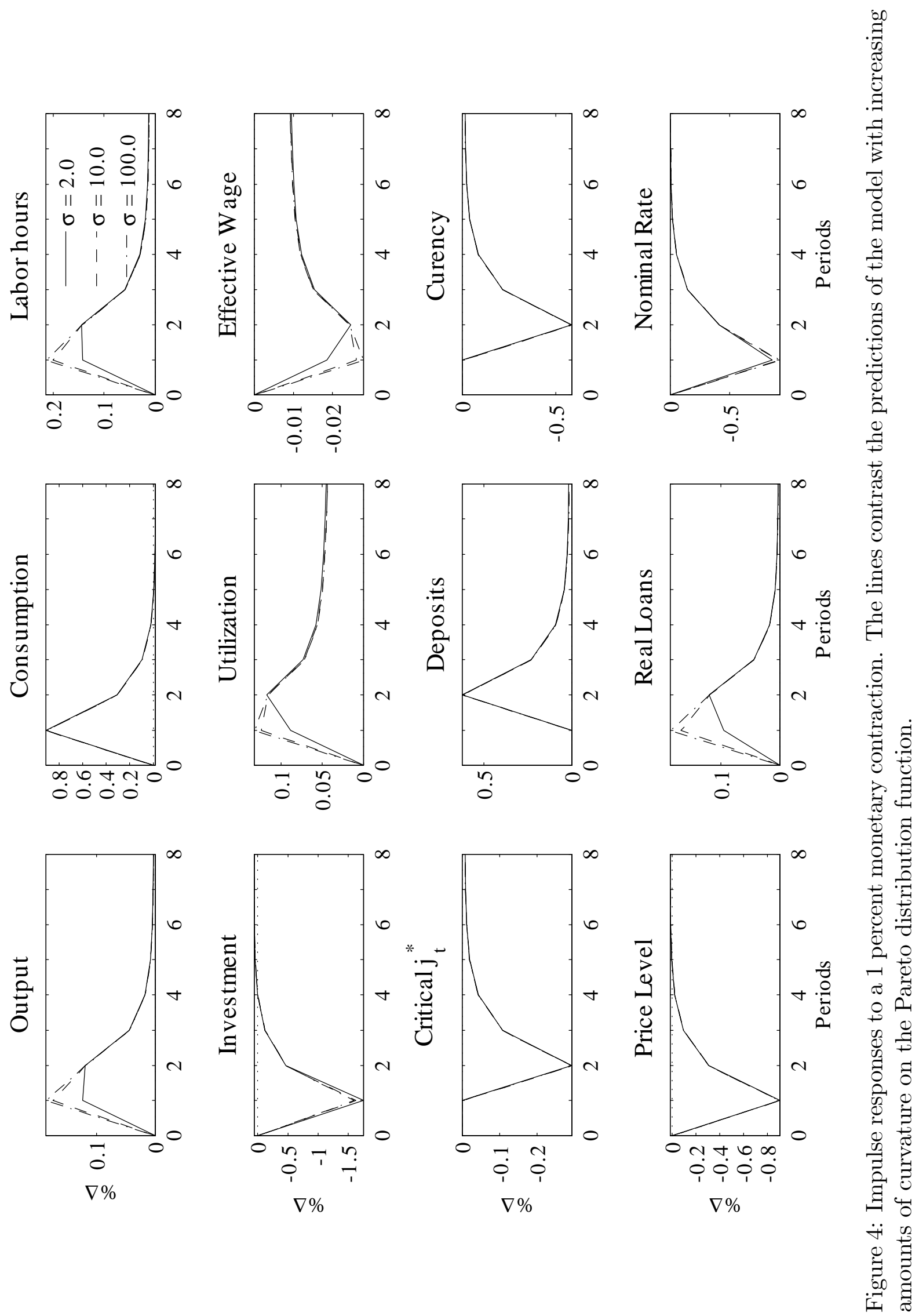

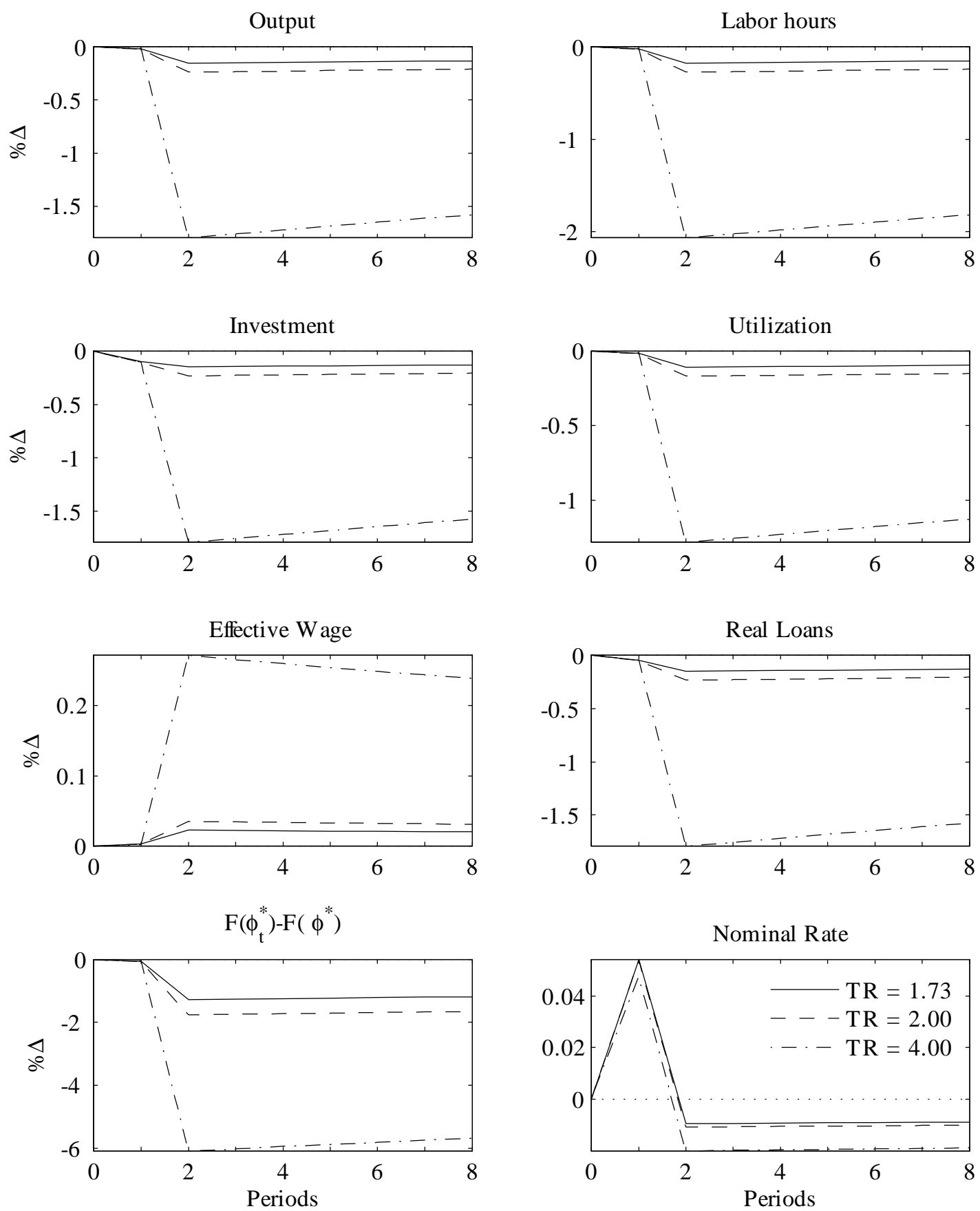

Figure 5: Impulse responses to a 25 basis point increase in the annual interest rate paid on reserves. The lines indicate the predictions of the model with 7.3, 10.0, and 30.0 percent steady state excess reserves, respectively. 